Anthropocene," Avidly, Los Angeles Review of Books, March 22, 2015, http://avidly.lareviewofbooks.org/2015/03/22/the-inhuman-anthropocene/; and Steve Mentz, "Enter the Anthropocene, Circa 1610," in Anthropocene Reading, 43-58.

5. See Eric Gidal, Ossianic Unconformities: Bardic Poetry in the Industrial Age. (Charlottesville: University of Virginia Press, 2015); Noah Heringman, "Deep Time at the Dawn of the Anthropocene," Representations 129 (Winter 2015): 56-85.

6. Christophe Bonneuil and Jean-Baptiste Fessoz, The Shock of the Anthropocene: The Earth, History, and Us, trans. David Fernbach (New York: Verso, 2016), 199.

\title{
Author
}

\section{ANDREW ELFENBEIN}

$I^{\mathrm{N}}$ $\mathrm{N}$ a typical literary critical essay, the author, rather than being a consistent concept, shifts rapidly among different, sometimes incompatible assumptions, evidence, and purposes: a biographical person, a synonym for the narrator, an implied presence governing an entire work, a metonym lending coherence to a career, an item in a list characterizing a movement or a period, the receiver or producer of literary or contextual influences. This mosaic is and is not productive. It enables a shorthand that lets literary critics gloss over complex, messy questions to zero in on textual analysis. Yet those messy questions never go away and haunt the margins of analysis with unfinished business. Literary critics have not ignored Foucault's "What is an Author?" but they have skipped its relevance to their own practice. ${ }^{1}$ The large question of "What is an author?" has blocked the smaller but more pressing question, "What should an author be in a work of literary criticism?"

I list some familiar manifestations of the author found in much literary criticism. I developed this list by generating all the different versions of the author that appeared in a single paragraph in a representative work of Victorian literary criticism; I am less interested in criticizing this work than in describing figurations of the author found throughout scholarship. 
1. Author as Mind: Authors' minds are not accessible except through their writing. So, using a post hoc propter hoc logic whereby causes are known by their effects, critics use authors' works to posit pre-existing minds as their origin. Thoughts are assumed to be in a mind in the way that a chair is in a room. Language is the vehicle whereby this internal thought receives external expression. In such formulations, written language mirrors thought: the existence of language as a code with conventions and restrictions at the level of phonology, morphology, syntax, and semantics that might influence or affect writing rarely matters. Writing is the pure imprint of the author's mind. ${ }^{2}$

2. Author as the Object of Evaluation: Although contemporary criticism has moved away from the evaluative language of earlier criticism, evaluations rarely remain absent. Critics may judge an author's work, but they also judge authors' life choices, politics, religion, and romantic choices, especially when these do not conform to early twenty-first century mores. Such evaluations say as much about the critics doing the judging as they do about the authors, but the occasion for making them remains a powerful motive for the author's presence in criticism.

3. Author as Biographical Fact: Although authorial texts are open to interpretation, biographical facts usually occupy the status of unquestioned truth in literary critical essay. Moreover, these facts are held to be relevant to criticism, as if the New Critics had never raised the possibility of the biographical fallacy. ${ }^{3}$ What puzzles me most is that life is assumed to be an obvious and straightforward origin for writing. The transformative work that goes into turning autobiographical memories into writing can be glossed over through reference to biographical fact. Such fact is held to have weirdly coercive power over authorial agency, as if the fact that something happened to an author necessitated that he or she write about it. Yet authors experience many things that they do not write about, and write about many things that they have not experienced. Yet, at least for this figuration of the author, at some level, even things that do not seem to be directly rooted in autobiographical experience can, with enough ingenuity, be linked to it.

4. Author as Views: In this version of the author, works by an author advance a view, which becomes a metonym for the whole. Just what it means for a work to express a view is not specified: how often does the view have to be articulated? By whom? In what contexts? How do we recognize a view that is "advanced" from one that just appears but cannot stand as a metonym for it? Such views supposedly belong not only to works but also to authors because they are the source. As such, the 
author is a principle of coherence whereby a work written earlier in a career is relevant many years later, although the person who wrote earlier may have quite different biographical, financial, and authorial circumstances from the one who wrote later. Literary critics more generally assume that authors' views remain constant unless there is evidence to the contrary. Whether or not views remain consistent can be a topic of controversy, but both sides agree that authors' works are appropriate evidence for judging their views.

5. Author as Producer of Complexity: This is a slippery category. Longstanding disciplinary practice encourages critics to view works in terms of ambiguities, contradictions, and tensions, and noticing such has become a hallmark of worthwhile criticism. Yet just how they arrived there is not certain. At times, the work becomes a metonym for the author, as if the work's complexities have an origin in the author's uncertainties or confusions. At other times, as Amanda Anderson has argued, authors receive "aggrandized agency," whereby they rise above the contradictions of their historical moment to offer a privileged perspective; Anderson noted this aggrandizement especially in feminist criticism, but it is present more broadly. ${ }^{4}$ Scholars may also treat tensions in a work as reflections of tensions in a culture. While critics may shy away from assuming that a work directly reflects a historical moment (although, as I have noted, they do assume such reflection with respect to biography), they locate the source of a work's contradictions in larger contradictions of a discourse.

This list arose from reading one paragraph in the work of one critic: a broader survey of criticism would yield many more images. Almost from sentence to sentence in literary criticism, the author is a shapeshifter, varying in function, evidence, and agency. Henry James complained that nineteenth-century novels were "large loose baggy monsters." If James were to look at Victorian literary criticism, however, he would find that loose baggy monstrosity has not disappeared but has found a new home: the author. Intense focus on textual analysis has come at the expense of figuring the author coherently. Before close textual scrutiny can continue productively, literary critics need to confront unsettling questions about authorship that have for so long been swept aside.

\section{Notes}

1. Michael Foucault, "What is an Author?," in Aesthetics, Method, and Epistemology, trans. Josué V. Harari, ed. James D. Faubion (New York: New Press, 1998), 205-22. 
2. For a powerful criticism of this figuration of the author, see Nancy Armstrong and Leonard Tennenhouse, "The Mind of Milton," ch. 1 of The Imaginary Puritan: Literature, Intellectual Labor, and the Origins of Personal Life (Berkeley: University of California Press, 1992), 27-46.

3. For the classic New Critical statement, see Frank H. Ellis, "Gray's Elegy: The Biographical Problem in Literary Criticism," PMLA 66, no. 6 (1951): 971-1008.

4. Amanda Anderson, "The Temptations of Aggrandized Agency: Feminist Histories and the Horizon of Modernity," Victorian Studies 43, no. 1 (2000): 43-65.

5. Henry James, Preface to The Tragic Muse (New York: Charles Scribner's Sons, 1922), x.

\section{Authorship}

\section{ANDREA SELLERI}

$\mathrm{L}$ ET us imagine that a diverse group of scholars of English literature were asked to provide a one-minute explanation of why authorship is a worthwhile subject for academic enquiry. Prima facie, the facts of the matter seem straightforward: a person conceives a series of ideas, puts them in writing, and publishes them; if enough people are prepared to pay to read the results, the author gets a share of the profit; if the writing brings about a crime or misdemeanour (e.g. slander or plagiarism), the author is responsible in the eyes of the law. ${ }^{1}$ But in contrast to this straightforwardness on paper, literary scholars continue to produce an enormous quantity of research dealing with "authorship." Nor is this usually a matter of determining who wrote some unsigned piece (the most intuitive interpretation of the term). Articles are written, lectures given, bids for research grants tremulously penned to study a concept that to the layperson may not appear to need such an expense of intellectual application. So, why is authorship interesting?

I suspect that the immediate mental associations prompted by this bald request would be strikingly different for different literary scholars, depending on the prevalent directions that inquiry has taken in their subfield. Those of a philosophical bent, for example, would likely cast their 